\title{
A vOZ FALÍVEL - ENSAIO SOBRE AS FORMAC̣̃̃ES AMERÍNDIAS DE MUNDOS
}

\author{
Pedro de Niemeyer Cesarino
}

Universidade de São Paulo ${ }^{1}$

\section{Resumo}

Este artigo trata dos regimes narrativos ameríndios referentes à cena inicial do cosmos e suas respectivas modulações da agência criadora. Através da leitura de traduções de narrativas selecionadas, buscar-se-á refletir sobre o problema da voz demiúrgica e do estatuto ontológico dos agentes primeiros, passíveis de serem compreendidos como multiplicidades intensivas.

Abstract

This article is a study on Amerindian narrative cosmogonic scenes and its configurations of creative agency. Through the study of selected narratives, the text explores the problem of the demiurgic voice and the ontological status of the first agents, understood as intensive multiplicities.
Palavras-chave

Voz;

multiplicidade;

narrativas

ameríndias;

cosmogonia.

Keywords

Voice;

multiplicity;

amerindian

narrartives;

cosmogony. 
Deus disse: "Haja luz" e houve luz.

Gênesis 1,3

No princípio era o Verbo/ e o Verbo estava com Deus/

e o Verbo era Deus.

João 1,1

Eu sou uma voz que clama no deserto: endireitai o caminho do Senhor.

João 1,23

E o sétimo Anjo tocou [...]. Houve então fortes vozes no céu, clamando [...].

Apocalipse 11, $15^{2}$

Não havia nada no mundo, só gente - e jabotis!

(relato aikewara) ${ }^{3}$

Em tempos de discussão sobre a iminência do fim de um certo mundo, torna-se necessário refletir também sobre distintas concepções de seu começo. ${ }^{4}$ Vamos aqui tratar daquelas elaboradas pelas tradições narrativas ameríndias, sobreviventes do colapso de seus mundos originais pelas invasões europeias. Essas tradições autóctones em muito divergem daquela, de origem bíblica, que concebe a criação como efeito de uma figura central, hierárquica, vinculada à imagem paterna, portadora de uma voz autoritária. As matrizes ameríndias orientam-se por outras imagens do início e seus respectivos regimes de linguagem, possivelmente capazes de projetar outras configurações de realidade. De fato, postula-se, nas cenas iniciais ameríndias, algo próximo da dialogicidade, ao invés da voz imperativa e seu respectivo regime de autoridade É isso que podemos encontrar na leitura e na reflexão sobre algumas traduções de narrativas genericamente chamadas de "cosmogônicas", marcadas pela por uma voz múltipla e ativada, capaz de estabelecer vínculos com a mobilização da linguagem ritual dos tempos atuais. Marcadas pela falibilidade e pela incompletude, derivadas de figuras demiúrgicas distintas daquela que caracteriza o momento inicial da gênese cristã (Elohim, a divindade do Gênesis I,1), as narrativas ameríndias terminam por oferecer um outro registro da palavra, assentado em configurações ontológicas alternativas à agência criadora hierárquica que permeia a narrativa cristã. ${ }^{5}$ 
I.

Conhecido como um dos principais conjuntos de narrativas míticas escritas em uma língua ameríndia, o Popol Vuh dos Maya-Quiché da Guatemala é um livro sui generis. A versão que se tornou disponível para o leitor moderno, de acordo com Gordon Brotherston, "é uma cópia, feita em Rabinal, Guatemala, de outra cópia feita no povoado de Chichicastenango, também na Guatemala, do original maya-quiché do século XVI, que utiliza a escrita alfabética introduzida pelos conquistadores". ${ }^{6}$ Esse original, escrito em maya-quiché alfabetizado, tentaria copiar, fazer referência ou recompor um suposto antigo livro hieroglífico, perdido ou escondido pelos indígenas no contexto da invasão europeia e do advento da Cristandade. Mesmo que controversa, ${ }^{7}$ a existência de tal livro, que teria sido utilizado pelo autor anônimo do Popol Vuh alfabético, não elimina o papel fundamental do original para a construção do registro de autoridade desta narração, elaborada sob o jugo da colonização. É o que se pode constatar pela leitura de um trecho do primeiro canto:

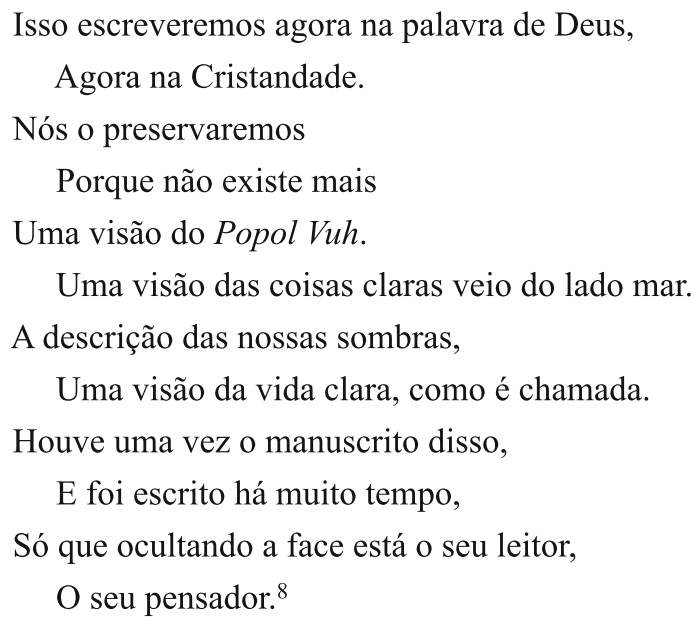

O livro original não seria apenas um suporte escrito para um determinado conteúdo narrativo mas, também, um instrumento de visão, utilizado para que os vestígios da presença divina pudessem ser perseguidos e manipulados pela agentividade ritual, assim fazendo com que o divino pudesse ser visto. Isso se torna claro em uma versão inglesa dos mesmos versos acima citados, oferecida por Dennis Tedlock: "We shall bring it out because there is no longer a place to see it, a Council Book, [...] a place to see "The Dawn of Life". ${ }^{9}$ Esse lugar, ou seja, o próprio Popol Vuh ou "Livro do Conselho", não poderia mais ser encontrado no manuscrito colonial, defasado e empobrecido com relação àquela outra forma de ativação da linguagem e de sua extensão em concepções de livros bastante singulares comuns às tradições maya e nahuatl.

De que trata, afinal, o manuscrito em questão? O Popol Vuh narra feitos diversos, tais como a formação do mundo, o surgimento e a destruição das quatro humanidades, os feitos dos gêmeos Hunahpu e Xbalanque, as guerras e transformações dos antigos Maya-Quiché. Seu trecho inicial, que versa sobre a formação do mundo (genericamente chamada de "criação" ou de "cosmogonia" pelos estudiosos modernos ${ }^{10}$ ) foi considerado por alguns como 
uma mera paráfrase da gênese cristã. Em um estudo dedicado a desmontar as razões de tal equívoco perpetrado pelos estudiosos, Tedlock elenca uma série de argumentos em favor de uma elaboração original da cena primeira narrada pelos Maya-Quiché. Ela coloca em jogo uma tríade de divindades-furacão, tomada pela leitura cristã como uma paráfrase da Santíssima Trindade. ${ }^{11}$ Como se não bastasse isso, o Popol Vuh ainda atribui a tal tríade a formação da terra através da palavra:

Assim a Terra foi criada por eles.

Só a palavra deles causou a sua criação.

Para criar a Terra, "Ulev" ("Terra"), eles disseram.

Imediatamente ela foi criada.

Era apenas como uma nuvem,

Como uma névoa então,

A criação então,

O furacão.

Então à montanha foi dito que saísse da água.

Imediatamente houve grandes montanhas.

Só o poder deles,

Só a magia deles

Causou a criação então,

A invenção

De montanhas

E vales. ${ }^{12}$

Ao evocar o poder da palavra ativada pela voz de comando demiúrgica, o trecho em questão servia como uma comprovação de uma suposta adaptação da cena primeira do Gênesis. Para Tedlock, essa leitura enviesada deixa de lado a originalidade do agenciamento ritual envolvido na cena, que seria independente da provável alusão do narrador à gênese cristã:

\begin{abstract}
Apenas algumas linhas adiante, a sentença xa quitzih, "apenas suas palavras" ["só a palavra deles causou a sua criação", na versão acima], é conjugada a xa quinaual, xa quipuz, "apenas o seu nahual, apenas o seu puz" ["Só o poder deles/ Só a magia deles", acima], que reduz "apenas as suas palavras" ao estatuto de uma entre outras figuras de fala para um ritual maior que envolve muito mais do que $t z i h$, "palavras". Em quiché, nahual se refere à essência espiritual ou ao caráter de uma pessoa, animal, planta, pedra ou espaço geográfico; quando é usada, tal como aqui, como uma metonímia para o poder xamânico, ela se refere à habilidade de tornar visíveis ou audíveis essas essências através do ritual. Puz [...] se refere literalmente ao corte da carne com uma navalha, e é o termo principal para sacrifício. Se, na presente passagem, for lida como uma sinédoque, ela significará que a criação foi realizada (em parte) através de sacrifício; se lida como uma metáfora, significará que a criação foi algo como um sacrifício. ${ }^{13}$
\end{abstract}

Em sua própria tradução do Popol Vuh, publicada alguns anos após o artigo acima citado, Tedlock traduz o trecho em questão da seguinte forma: "By their genius alone, by their cutting edge alone they carried out the conception of the mountain-plane". ${ }^{14}$ Com essa solução, o autor pretendia aproveitar as especificidades do pensamento maya-quiché que se 
faziam notáveis pela conjugação da palavra ativada ao nahual (noção intraduzível, associada à composição da pessoa, à ideia de duplo e aos princípios vitais) e ao puz, a ação sacrificial. Nas notas à sua tradução, lemos que tal sacrifício

$$
\begin{aligned}
& \text { implica que "as montanhas foram separadas da água" por um ato semelhante ao da } \\
& \text { extração do coração (ou de outros órgãos) através de um sacrifício. Para confirmar } \\
& \text { essa alusão, o texto segue se referindo à terra como a "planície-montanha", ou huyub } \\
& \text { tacab, que, hoje em dia, é a principal metáfora quiché para o corpo humano. }{ }^{15}
\end{aligned}
$$

Para elaborar tal interpretação, alternativa à de outros tradutores centrados exclusivamente no texto do Popol Vuh, Tedlock se valia de uma pesquisa de campo com rezadores contemporâneos descendentes dos antigos Maya-Quiché, ontologicamente mais preparados para lidar com os meandros do antigo manuscrito do que tradutores ocidentais. Através do diálogo com don Andrés Xiloj, o antropólogo-tradutor conseguia mostrar como a presença do terceiro elemento em questão, o nahual, supostamente descartaria a existência de um trabalho físico e aproximaria a cena primeira de uma certa ação não substancial [insubstantial], elaborada através do léxico imagético sacrificial. É o que Tedlock concluía a partir das seguintes considerações de seu interlocutor: "Então essas montanhas estão apenas para representar o fato de que há vales e vulcões". Ao que o antropólogo emendava o seguinte: "isto é, ele interpretava as montanhas não como realidades duras, mas como meros 'signos' (retal), desdobrando a si mesmas 'assim como uma nuvem, como uma névoa'".16

A aptidão ontológica do interlocutor quiché de Tedlock para compreender o Popol Vuhum texto do qual, no entanto, ele apenas havia ouvido falar e que lhe era apresentado com mais detalhamento pelo antropólogo - pode ser atestada através de um contraponto notável: a compreensão parcial do pensamento nativo por Tedlock, que não escapa de contaminar a sua interpretação com as sacrossantas dicotomias modernas (literal/metafórico, material/ imaterial). Ora, o universo conceitual quiché certamente articula níveis de elaboração da linguagem e de torções com relação ao seu uso ordinário. Nem por isso essas elaborações corresponderiam necessariamente ao uso literário (e fictício) de imagens metafóricas (a criação como um sacrifício), que seria empregada para figurar alguma ação imaterial das divindades. Algo, enfim, parece ainda resistir ao esforço de análise. Como vimos, a possibilidade de que o processo seja concebido como uma sinédoque não apenas abre caminho para um modo efetivo de transformação via agência sacrificial como, também, para uma outra semiótica envolvida na noção de retal (acima traduzida por Tedlock como 'signo') e seu processo cosmológico correspondente.

Além de articular um componente da pessoa e uma operação sacrificial - mas distinta, note bem, daquela empregada para livrar a humanidade ou a cidade de uma mácula ${ }^{17}$ - à palavra formadora, a cena inicial maya-quiché a transforma em um diálogo entre as divindades. Esse diálogo, nota Tedlock, "é uma força positiva, necessária antes que a criação sequer possa ser concebida, e é o primeiro passo para além dos murmúrios e vibrações sem sentido da cena primeva". ${ }^{18}$ Um diálogo que, segundo o autor, tem no Gênesis o papel oposto, uma vez ali ele surge como forma de despejo da cólera de Javé sobre os primeiros humanos pecadores. ${ }^{19}$ A cena inicial maya-quiché, por sua vez, não procede de "uma série de comandos provenientes de uma única fonte, mas sim de uma discussão aberta" ${ }^{20} \mathrm{O}$ ponto é notável em passagens como a seguinte, na qual os demiurgos se interpelam após a produção fracassada de uma humanidade de argila, incapaz de venerar as divindades: 
“Ele não era forte", disseram então

Tzakol

E Bitol.

"Ele parece úmido.

Se continuasse molhado

Não iria ser capaz de andar

E não chegaria a multiplicar-se.

Assim haveria de ser.

Sua mente está escura a esse respeito", eles disseram.

E assim eles o destruíram.

Eles espalharam de novo

O que eles haviam construído,

O que tinham modelado.

E eles disseram de novo,

"O que será que faremos

Que poderá agora ter êxito,

Que poderá agora ser inteligente,

Venerando-nos

E invocando-nos?", eles disseram.

Então pensaram mais

E logo invocaram

Xpiacoc

E Xmucane,

Hun Ah Puh Vuch,

Hun Ah Pu Utiv.

"Eles podem tentar fazer outra vez sua adivinhação,

Sua criação", eles disseram entre si-

Tzakol

E Bitol. ${ }^{21}$

Além de colocar uma constelação de divindades em diálogo, o Popol Vuh também aponta para a falibilidade das ações primeiras, que tardam em conseguir produzir uma humanidade efetivamente capaz de venerar os seus produtores. Ações falíveis, agentes que, por conta própria, não logram produzir mundos: a unidade parece se mostrar tão improvável quanto os seus comandos; ela passa a ser substituída por uma dualidade instável, assimétrica, potencialmente múltipla, e por isso produtora de ações irredutíveis ao acabamento do comando imperativo.

II.

Tais contornos ontológicos não são notáveis apenas na narrativa maya-quiché. Guardadas as devidas diferenças etnográficas, as narrativas de povos das terras baixas sulamericanas oscilam entre apresentar uma dialogicidade mais ou menos explícita em suas cenas 
primeiras. Em alguns dos volumes da Coleção Narradores Indígenas do Alto Rio Negro, ${ }^{22}$ uma das mais importantes compilações de narrativas ameríndias recentemente produzidas, a divindade primeira Avô do Universo desdobra-se constantemente ("faz" ou "cria", a depender da tradução) em outras divindades, com as quais eventualmente compartilha, através de decisões travadas em um aparente diálogo, as ações responsáveis pela formação progressiva do mundo. "Cansado de viver sozinho", ${ }^{23}$ o demiurgo dos narradores Desana-Wari Dihputiro Porã faz outras "gentes do universo" com as quais, em um determinado momento, entretém o seguinte diálogo sobre o difícil processo de formação do mundo:

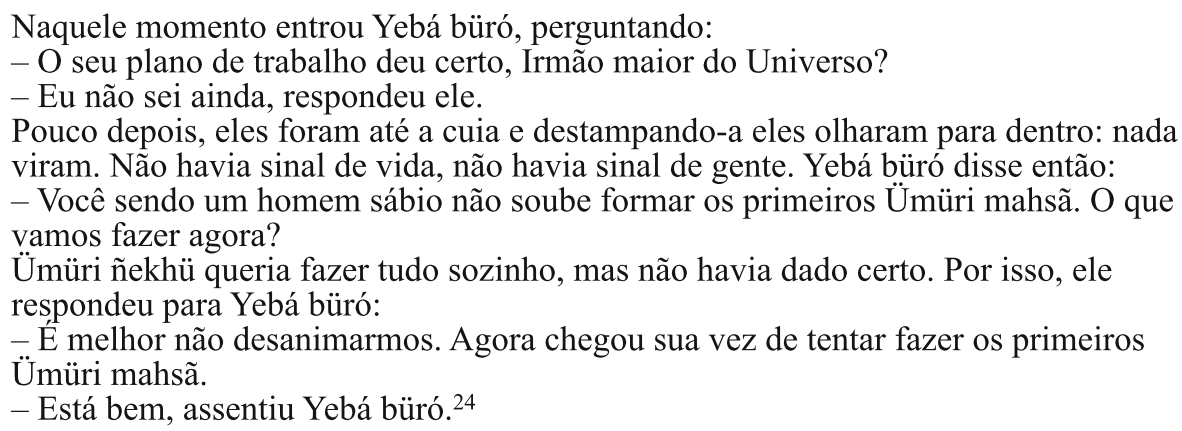

Na versão dos narradores Tukano Hausirõ Porã, não encontramos um demiurgo cansado de si mesmo, ansioso por se desdobrar em seus pares, mas sim um Avô do Universo que empreende solitário a sua "criação" (este é o termo privilegiado na tradução, marcada por uma série de comandos imperativos). Valendo-se de seu bastão, da ingestão de ipadu, da fumaça de tabaco (mas um tabaco diferente do atual) e de outros instrumentos rituais, ele "[tem] várias ideias e [começa] a executar seus planos". ${ }^{25}$ No entanto, suas "rezas", "benzimentos" ou "orações", associadas à manipulação de substâncias e seus suportes rituais, envolvem um procedimento delicado, sujeito a interrupções e instabilidades passíveis de comprometer o seu sucesso final:

\footnotetext{
Terminando a oração, Avô do Universo soprou a fumaça do cigarro bem na direção de suas criações, o suporte de cuia e a cuia de ipadu. O suporte de cuia começou a se mexer e fazer barulho, mas sumiu. Avô do Universo insistiu. Vendo que não estava dando certo, pensou e disse:

- Eu estava criando, vou continuar.

Dizendo isso, Avô do Universo pegou sua forquilha de cigarro e se sentou embaixo, abençoando... ${ }^{26}$
}

Decorrente ou não de influências salesianas, a ênfase em uma figura única e nos comandos imperativos dada por esta versão não esconde a possibilidade da falha na ação demiúrgica assentada na voz benzedora. Uma voz que, assim como no caso do Popol Vuh, não existe por si só como veículo de transformação cosmológica, pois se ativa através de sua associação com outros vetores de potência ritual, entre os quais o sopro potencializado pelo tabaco. É digno de nota que a unidade de Avô do Universo se desfaça nesta outra versão do diálogo inicial, desta vez apresentada por narradores Desana Guahari Diputiro-Porã:

Como vai ser para nós aqui, bisavô?, perguntou Baaribo para Bupu. Somos somente três! Precisamos fazer alguma coisa! Como vamos fazer aparecer as futuras gerações? Como vamos fazer nascer os outros? $?^{27}$ 
Vemos aí a dialogicidade recuperar novamente o seu estatuto central na cena primeira, que havia sido concebida pelos narradores Tukano Hausiro Porã (ou então transformada pelo processo tradutório) como uma série de comandos provenientes de um agente masculino mas, ainda assim, falível. Não é apenas a unidade imperativa que se desestabiliza nas distintas versões da Coleção Narradores do Alto Rio Negro. No primeiro volume editado, a própria anterioridade da figura masculina passa a ser substituída. Na narrativa dos Desana Umúsin Panlõn Kumu e Tolamãn Kenhíri, ${ }^{28}$ a posição demiúrgica cabe à Avó do Universo, que se faz a si mesma a partir de coisas preexistentes (bancos, suportes de panelas, cuias, ipadu, pés de maniva e cigarros) e é por isso chamada de "a não criada" ${ }^{29}$ Solitária em seu compartimento de quartzo iluminado, que se torna rodeado pela escuridão envolvida pela expansão de seu pensamento-esfera (ou ëmëkho patolé, universo, barriga), Avó do Universo faz cinco homenstrovão através do ipadu retirado de sua boca. Os homens-trovão, chamados por ela de irmãos, passam a viver nos compartimentos de tal universo concebido à semelhança de uma maloca. Ali, recebem uma instrução de sua formadora na seguinte passagem notável:

Os quartos dos trovões tornaram-se casas chamadas ëmëkho wiri [universo, casas]. Cada qual ficou morando numa casa. Ainda não havia luz. Só nessas casas fez-se a luz, do mesmo modo como na casa da avó do universo. Todo o resto do mundo continuava na escuridão. Yebá bëló disse então aos trovões: "Gerei vocês para criarem o mundo. Cabe-lhes, agora, imaginar um modo de fazer a luz, fazer os rios e a futura humanidade, a pamani mahsá aninbolá [transformação, gente que vão ser (sic)]". Eles responderam que assim fariam. Mas nada fizeram. Cada qual ficou na sua casa e nem lembraram o que Yebá bëló lhes havia dito. ${ }^{30}$

$\mathrm{Na}$ sequência da narrativa, Avó do Universo segue cobrando os homens-trovão, que falham sucessivamente nas tarefas de transformação. O lugar estrutural que, no Popol Vuh, é ocupado pelos sucessivos fracassos em conceber uma humanidade capaz de venerar as divindades se desloca, aqui, para o interior das próprias séries divinas ou extra-humanas: após se desapontar com os irmãos-trovão, Avó do Universo decide fazer outro ser capaz de cumprir as suas demandas, que surge novamente a partir da fumaça de seu cigarro e, assim como antes, chega à existência ao receber um nome.

III.

Nomeação, formação de multiplicidades a partir de uma unidade instável e propensa à multiplicação, conjugação da palavra a instrumentos e substâncias de transformação: tais são os traços comuns que, associados à falibilidade e à suposta dialogicidade, não marcam apenas as narrativas referentes aos tempos antigos, mas se estendem também para as ações rituais dos tempos de hoje. Não por acaso, os pajés rezadores $(k u b u)$ do Alto Rio Negro se valem, em seus cantos de cura, da voz ativada pelo tabaco, dos bancos outrora utilizados pelos demiurgos e, mais ainda, de um procedimento de nominalização análogo ao encontrado nos processos de formação do mundo e dos animais realizados em outros tempos. ${ }^{31}$ Mas não é apenas a estrutura dos cantos e a configuração ritual que replica os eventos antigos: os cantos em si são infalíveis, assegura Buchillet, ainda que possam ter a sua eficácia comprometida por algum deslize de condução do rezador que, eventualmente, erra os nomes dos agentes visados (elencados em listas paralelísticas) ou se confunde em seu diagnóstico. Tais erros, aliás, 
poderão ser reparados ao longo dos diálogos empreendidos entre o aprendiz e seus mestres, ciosos em transmitir o difícil e rigoroso "poder de interferir na ordem das coisas" 32 através das palavras.

Algo similar é encontrável também entre os pajés rezadores (kêchitxo) marubo (falantes de Pano do Vale do Javari), ${ }^{33}$ que atribuem os problemas na eficácia de determinados rituais ao despreparo e às falhas de aprendizagem, mas jamais ao sistema dos cantos de cura (chinã vana). Ora, tais cantos, assim como no caso dos falantes de tukano do rio Negro, operam através de procedimentos que remontam à própria constituição do mundo nos tempos primeiros, tão sólida e real quanto a própria capacidade virtual das palavras de recuperar os processos de formação do mundo através da ação verbal, empoderada por substâncias como o suco de tabaco, a ayahuasca e o rapé. Um dos aspectos dos longos cantos shõki é, mais uma vez, a nomeação precisa das entidades agressoras, que devem ser "aconselhadas" (esea) pelo cantador a abandonar a "carcaça" do paciente (shaká, uma maloca-corpo do ponto de vista de seus habitantes internos), ou a deixar em paz o seu "duplo" (vaká). Apesar de empregar uma série de armas e poderes utilizados pelas multidões de espíritos auxiliares (as Shoma) em suas batalhas invisíveis contra os agressores, o pajé condutor da ação não "briga" (vatxĩa) propriamente com tais intrusos, mas os "aconselha" ou os convence a partir, através de um diálogo estendido pela sequência paralelística de versos. ${ }^{34}$ Dessa forma, o agenciamento ritual xamanístico replica em seus procedimentos o sentido de outra modalidade fundamental das artes da palavra entre os Marubo: a "fala de ensinamento" (ese vana), uma marca distintiva de tal povo que se considera como "sábio" (chinãivo yora, "gente pensadora/sábia") por oposição aos seus outros vizinhos e antepassados belicosos (pakayavo yora, "gente brava/guerreira"). Nisso reside toda uma ética da palavra e do emprego social da voz, cuja modulação jamais deverá expressar cólera ou alguma forma de ódio autoritário que, mesmo se empregada por alguma figura de importância, terminaria por minar a sua eficácia política. Trata-se de algo bastante próximo das famosas considerações de Clastres $^{35}$ sobre a chefia ameríndia e sua invenção de uma sociedade contra o Estado, na qual a palavra do chefe não pode ser jamais a palavra de soberania autoritária.

Com isso chegamos à cena primeira, narrada pelos Marubo através dos longos e complexos cantos saiti. Ela parece servir como matriz para a formação de tal ética da palavra que, de fato, recusa a possibilidade de uma agência externa, autônoma, soberana e anterior aos processos responsáveis pela formação das "pessoas verdadeiras ou prototípicas" (yora koin) no decorrer da vida entre parentes. O nexo relacional presente na cena primeira, já existente antes de a atual sociedade se configurar, não deixa de se elaborar pela mesma dialogicidade que modula os tempos presentes. É o que vemos no trecho de abertura da "Fala da Terra Névoa" (Kõ̃ Mai Vana) cantada por Armando Mariano Marubo (Cherõpapa), na qual o demiurgo Koĩ Voã surge a partir de uma espiral de ventos, dando início ao aparecimento de seus outros pares com os quais formará o mundo:

$\begin{array}{ll}\text { 1. Kõ shõpa weki } & \text { Vento de lírio-névoa } \\ \text { We votivetãki } & \text { O vento envolvido } \\ \text { Koi rome weki } & \text { Ao vento de rapé-névoa }\end{array}$


Veõini otivo

5. Koĩ shõpa weki

Chíkirinatõsho

Koì Voã wení

Awẽ askámaĩno

Tene tewã nãkoki

10. Nãko osõatõsho

Pikashea wení

Wenikia aíya

Otxoko iniki

Pikashea wení

15. Weníkia aíya

Vari tewã nãko

Nãko osõatõsho

Vari Tokẽ wení

Weníkia aíya

20. Shane tewã nãkoki

Nãko osõatõsho

Shane Tokẽ weni

Weníkia aíya

Ino tewã nãko

25. Nãko osõatõsho

Ino Tokẽ wení

Weníkia aíya

Kana tewã nãkoki

Nãko osõatõsho

30. Kana Tokẽ wení

Weníkia aíya

Wení mashtesho

Koĩ shõpa weno

Ronokia ashõki

35. Chinãkia aíya
Há tempos flutua

Vento de lírio-névoa

Vai se revolvendo

E Koĩ Voã surge

Enquanto isso

No néctar-tene

Dentro do néctar

Pikashea surge

O surgimento ocorre

Junto a Otxoko

Surge Pikashea

O surgimento ocorre

No néctar-sol

Dentro do néctar

Tokẽ-Sol surge

O surgimento ocorre

No néctar-azulão

Dentro do néctar

Tokẽ-Azulão surge

O surgimento ocorre

No néctar-jaguar

Dentro do néctar

Tokẽ-Jaguar surge

O surgimento ocorre

No néctar-arara

Dentro do néctar

Tokẽ-Arara surge

O surgimento ocorre

O surgimento terminado

Vento de lírio-névoa

No vento planam

E planando pensam 
"Txipo kaniaivo

Txipo shavá otapa

Awekima tsakai

A shokomisi?"

40. Ikianõ anã

Koĩ shõpa wenõ

Ronokia ashõki

"A anõ neskai

Noke enetipa"

45. Aki chinãvaiki

Awẽ yove kemo

Pakekia ashõki

Mai shovimaya

Kemo rane saiki

50. Toako atõsho

Mai shovimashõki

Shokopake voãsho

Chinãkia aíya
"Os nascidos depois

Nas outras épocas

Onde será que

Poderão viver?"

Assim eles dizem

Vento de lírio-névoa

No vento planando

"Deixá-los assim

Nós não podemos"

Pensam e então

Salivas-espírito

Salivas cospem

Para terra formar

Bolhas de saliva

Por tudo espalham

Terra inteira fazem

E vão ali ficar

Assim pensam ${ }^{36}$

Os espíritos demiurgos, cuja multiplicidade é marcada pelos classificadores que acompanham os seus nomes (névoa, tene, sol, azulão, jaguar, arara), ${ }^{37}$ surgidos a partir de um princípio transformacional primeiro (nãko, recriado por mim como "néctar"), não foram criados a partir de uma gênese sexuada e não têm gênero definido. A rigor, eles não são anteriores ao que, noutras ontologias, é concebido como uma criação posterior ao Um (Yahweh): aparecidos na sequência de um estado cosmológico preexistente, os demiurgos "surgem" ou "emergem" (wenía) sem serem antes "formados" (shovia) por alguém. O primeiro processo de "formação" só ocorre no verso 48, após o diálogo inicial, no qual os agentes primeiros, mais uma vez, manifestam entre si as suas dúvidas. Suas palavras, aliás, nada seriam se não se associassem a outros vetores transformacionais: a "saliva espírito" capaz de veicular os seus "pensamentos vitais" (chinã, categoria similar ao nahual mesoamericano), uma tradução insuficiente para esta imaginação demiúrgica presente em outras várias narrativas ameríndias e, evidentemente, irredutível a uma representação mental. Na sequência da narrativa, tal como no Popol Vuh e nas narrativas rio-negrinas, os demiurgos marubo lançam mão de uma série de outros elementos para "montar" ou "formar" (traduções possíveis de shovia) o mundo, que não decorre apenas de suas palavras: "Caule de tabaconévoa/ Caule atravessam/ E deixam deitado/ Toco de tabaco-névoa/ Colocaram cruzado/ E deixam deitado/ Tabaco-névoa ventando/ A terra formam/ E vão ali ficar/ Assim pensam". ${ }^{38} \mathrm{O}$ 
tabaco extraordinário, presente em outras narrativas como transformador cósmico a partir de sua fumaça, aqui reaparece como material (potente, primeiro) colocado à disposição dos demiurgos para suas tarefas.

A montagem do mundo é também realizada através de pedaços de antas e outros animais que, segundo a versão cantada por Paulino Memãpa, foram feitos a partir de seus sopros-vozes (koshoka) empoderados pelo caldo de lírio (análogo ao atual lírio ou trombeta-de-anjo, Brugmansia sp., mas melhor) e mortos, logo em seguida, para serem empregados na sustentação do mundo. O procedimento evoca a imagética verbal sacrifical maya-quiché mas termina por seguir outra direção, pois o problema aqui não é o do desmembramento da vítima (potencialmente utilizado como metáfora cósmica, dizia Tedlock), mas sim o seu esquartejamento e uso como material de fabricação. O resultado, no entanto, é similar, pois levará à separação progressiva entre céu e terra. Vale atentar para a continuidade dos procedimentos rituais primeiros e atuais: koshoka, "soprocantar", termo formado a partir da onomatopeia koshhh e do auxiliar -aka, se refere à estratégia utilizada nos dias de hoje para ativar a voz através de substâncias dotadas de chinã.

IV.

No Ayvu Rapyta, narrativa guarani mbyá dedicada ao surgimento do mundo originalmente recolhida e publicada por León Cadogan em 1946, também encontramos uma divindade posterior a um estado cosmológico preexistente. Algo similar ao que Curt Nimendajú registrou entre os Guarani Apapocuva, para os quais a divindade Nandevuruçu surgia solitária, em um estado primeiro já povoado pelos Morcegos Eternos, "que lutavam entre si em meio às trevas". ${ }^{39}$ Namandu, o equivalente de Ñandevuruçu para os Mbya, é por sua vez explicado a Cadogan pelos narradores indígenas como "pai", talvez pelo fato de a versão ter sido recolhida para circular em um contexto distinto do original. A esse respeito, Cadogan nos oferece a seguinte consideração do cacique Che'iro: "Papa es bueno para los jurua - cristianos -, pero no para nosotros para quienes Ñamandu es el Primero, ni para ti quien buscas la buena sabiduría entre nosotros". ${ }^{40}$ Namandu não é gerado por alguma causa externa a si mesmo, não surge de um Ovo cósmico ou de uma gênese sexuada ${ }^{41}$, que também não é a forma privilegiada para os seus desdobramentos subsequentes. A partir do surgimento de Ñamandu, o desenvolvimento da narrativa de fato tem mais a ver com derivações por replicação do que com as consequências desencadeadas pelos comandos causados por uma ação soberana. "Ele" (se é que cabe tal individualização pressuposta pelo pronome) se desdobra a partir "do saber das coisas", da "compreensão divina" (tradução de Clastres para mba'ekuaa, "divina sabiduría" para Cadogan), uma categoria talvez próxima do chinã de que se valem os demiurgos Marubo. Vale ler o trecho de abertura pela tradução de Clastres, que tenta calibrar os excessos de cristianismo da versão pioneira de Cadogan:

Nosso pai, o último, nosso pai, o primeiro

fez com que seu próprio corpo surgisse

da noite originária. 


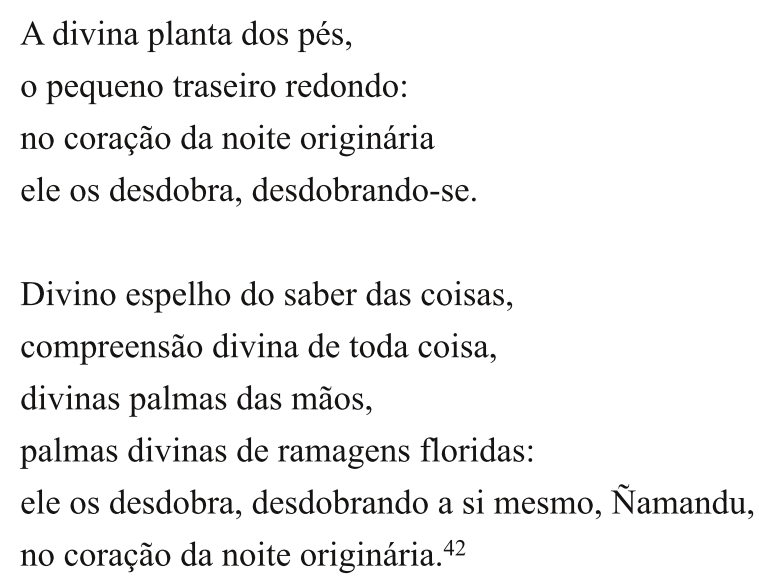

Ñamandu não é propriamente um indivíduo de contornos definidos; tampouco sua agência produz decisões imperativas derivadas de uma única fonte. Ao menos em uma das versões disponíveis do texto, a de Clastres, a agência não parece coincidir com a de uma figura personificada, autoritária e autossuficiente (o Pai), e deverá ser entendida por outra forma de configuração. De maneira similar a Omalyce, o Demiurgo-um dos Iqwaye da Melanésia, ${ }^{43}$ Ñamandu também coincide com o próprio mundo ou, a rigor, com a dimensão possível deste momento em que ele surge, mas a partir de um estado preexistente e da companhia de Maino, o "alimentador divino de Namandu", o colibri que dá frescor aos seus lábios, e de Urukure'a, a coruja que dá existência às trevas. ${ }^{44}$ No caso melanésio, Omalyce, "auto-nascido", ${ }^{45}$ está dobrado sobre si mesmo, com os dedos das mãos entrelaçados aos dos pés e a boca no pênis, identificado ao seu cordão umbilical. Estabelece-se dessa forma um sistema fechado de circulação (da água-sêmen primordial) e um estado de latência que só se desfará quando de seu desdobramento/descolamento, correspondente à abertura de sua boca e à separação dos dedos, assim produzindo a liberação dos fluxos e a formação das regiões do mundo. Esse gesto instaura não apenas o surgimento das dimensões cosmológicas mas, também, dos próprios Iqwaye, que são concebidos como instanciações de Omalyce, ou seja, como totalidades que recapitulam, em escalas distintas, a totalidade original. ${ }^{46} \mathrm{Tal}$ como traduzido por Clastres, o estado de latência Ñamandu, por sua vez, desconhece a noite, é anterior ao Sol e ainda não se desdobrou em sua própria morada. Ele ainda "habita o coração do vento originário":

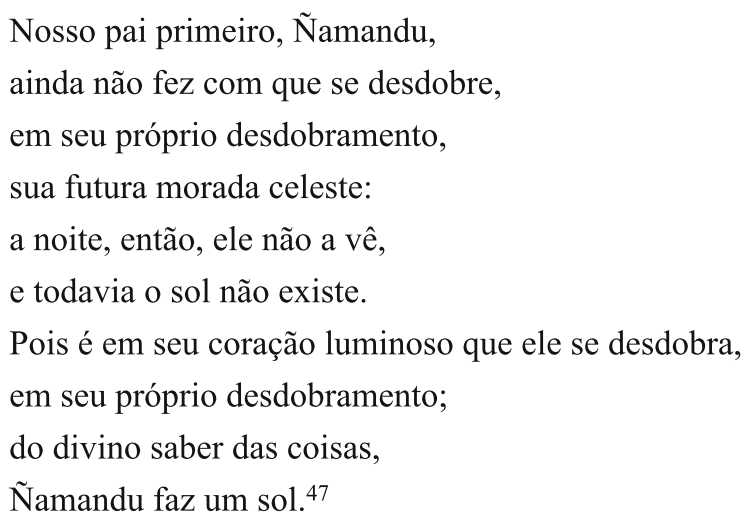


Não é, pois, apenas a partir de um descolamento/desdobramento gestual, como no caso da abertura de Omalyce-círculo-um para o mundo diferenciado, que Ñamandu faz o Sol. Como vemos a seguir, o movimento corporal também se fará presente nas derivações de Ñamandu, mas associado ao poder de seu "saber divino" (mba'ekuáa) que dá origem ao fundamento da linguagem, anterior à existência da humanidade, aos contornos cosmológicos e ao surgimento de suas divindades-pares. É nesse ponto que o problema da agência se torna notável, sobretudo se examinado a partir da diferença entre as distintas soluções tradutórias que seguem abaixo reproduzidas:

Pierre Clastres

Ele ergueu-se:

de seu saber

divino das coisas,/

saber que desdobra as coisas,

o fundamento da Palavra,

ele o sabe por si mesmo./

De seu saber divino das coisas,

saber que desdobra as coisas,

o fundamento da Palavra,

ele o desdobra desdobrando-se,

ele faz disso sua própria

divindade, nosso pai./

A terra ainda não existe,

reina a noite originária,/

não há saber das coisas:

o fundamento da palavra futura,

ele o desdobra então,/

ele faz disso sua própria divindade, /

Namandu, pai verdadeiro primeiro. ${ }^{48}$
León Cadogan

Habiéndose erguido,

de la sabiduría contenida en su

propria divinidad,/

y en virtud de su sabiduría creadora,/

concibió el origen

del lenguage humano./

De la sabiduría contenida en su

propria divinidad, /

y en virtud de su sabiduría creadora,/

creó nuestro Padre el fundamento

del lenguage humano/

e hizo que formara parte de su

propria divinidad.'

Antes de existir la tierra,

en medio de las tinieblas primigenias,/

antes de tenerse conocimiento de las cosas,/

creó aquello que sería el fundamento

del lenguage humano/

e hizo el verdadero Primer Padre

Namandu que formara parte de su

propria divinidad. ${ }^{49}$
Josely Vianna Baptista

Incorporando-se,

com o saber contido em seu

ser-tde-céu,/

e sob o sol de seu lume criador,

iluminou-se a fonte da fala.

Com o saber contido em seu

ser-de-céu,/

e sob o sol de seu lume criador, nosso Pai iluminou-se a fonte da fala/

e fez com que fluísse por seu ser, divinizando-a./

Antes de a terra existir, no caos obscuro do começo, todo oculto em sombras, Ñamandu, Pai verdadeiro, o primeiro,/ aflorou-se a fonte da fala e fez com que fluísse por seu ser, divinizando-a. ${ }^{50}$

Vemos aqui de maneira clara o que, na Coleção Narradores Indígenas do Alto Rio Negro, se torna menos evidente por conta das variações entre os distintos narradores e versões, ainda por cima transformada por soluções tradutórias duvidosas. Nas três versões do Ayvu Rapyta realizadas pelos tradutores modernos, no entanto, não é sempre constante essa ênfase na figura do indivíduo personificado, do autor ou causa primeira dos efeitos cosmológicos, do centro do qual decorreria a agência responsável pelas transformações do mundo. ${ }^{51}$ Os trechos acima grifados mostram como Cadogan se apoia explicitamente em tal figura personificada, ${ }^{52}$ provavelmente derivada do mundo do Livro, ao construir Ñamandu como o sujeito 
criador/produtor de determinados efeitos. Clastres, por sua vez, atenua tal posição ao enfatizar uma espécie de operação recursiva de desdobramento (terminologia aliás feliz, por desmantelar o peso semântico-metafísico da "criação" e por trazer a dinâmica do florescimento, cara ao pensamento guarani). A operação leva Ñamandu a expandir seus limites ou escalas externas na mesma medida das internas ("ele o desdobra desdobrando-se"), ainda que "ele", enquanto sujeito na construção do discurso, mantenha a sua posição. Vianna Baptista, por fim, altera a própria sucessão dos versos tendo em vista a produção de um efeito cíclico, de uma espécie de fluxo autorreflexivo ("iluminou-se", "aflorou-se"), muito embora, ao longo de sua versão, oscile de maneira pouco clara entre o "desdobrar" de Clastres e o "criar" de Cadogan. De fato, a voz agentiva de Ñamandu tende a romper o estado autoafetivo, o "espelho acústico" narcisista, ${ }^{53}$ como se tal enclausuramento fosse incompatível com o desdobramento já pressuposto por sua instabilidade anterior. Tal pressuposição mostra que o "outro" não corresponde a uma posição ameaçadora posterior, pois está implicado na definição da singularidade inicial.

Há que se perguntar, talvez de modo distinto do que pressupunha Lévi-Strauss em "A estrutura dos mitos", até que ponto o trabalho de tradução altera ou não o "mito" - esse conceito problemático do qual tenho me esquivado aqui. ${ }^{54}$ Pois se, como queria o antropólogo francês, o mito é justamente aquilo que melhor sobrevive às traições da tradução, não deixa também de ser verdadeiro que novos mitos se produzem (de maneira mais ou menos deliberada) justamente a partir das torções tradutórias. ${ }^{55}$ Afinal, qual entre as figuras (ou configurações?) demiúrgicas acima seria mais fiel ao pensamento narrativo postulado pelo texto original guarani? Faria sentido, aliás, perguntar por alguma forma de fidelidade, sem que isso se tornasse em um constrangimento ao trabalho inventivo de tradução? ${ }^{56}$ Se tais questões não têm uma resposta simples, caberia ao menos considerar um procedimento tradutório capaz de capturar, em sua própria engenhosidade, a originalidade do pensamento narrativo alheio, ao invés de tomá-la por outros mitos, ou pelo mito dos outros.

Cabe retomar, nesse ponto, o problema da dialogicidade via a provável não coincidência do agente com a figura do indivíduo demiúrgico personificado. Namandu desdobra o fundamento da palavra antes de que seus outros pares-derivações apareçam na sequência da narrativa. O fundamento da palavra é a condição de tais derivações ou, antes, um sintoma da sua inexorabilidade. Pois tudo se passa como se houvesse uma propensão incontornável para a multiplicidade da voz (que parece demandar um modelo alternativo ao da heteroglossia), justamente lá onde ela não se mostra tão explícita (ou seja, tanto quanto n' $A$ fala da Terra Névoa, no Popol Vuh, em algumas das narrativas rio-negrinas e na versão apapocuva de Nimuendajú). É o que vemos, mais uma vez, a partir do contraste entre as três traduções, referentes ao momento em que Namandu já desdobrou o fundamento da fala: 
Desdobrando o fundamento da Palavra futura,/

conhecido o Um, a fonte do canto sagrado,/

então, com força, seu olhar procura/ quem será encarregado do fundamento da Palavra,/

do Um que reúne,

de redizer o canto sagrado.

Com força, seu olhar procura:

do divino saber das coisas,

saber que desdobra as coisas, ele fez com que surgisse o divino companheiro futuro.
Habiendo creado, en su soledad, el fundamento del lenguage humano;/ habiendo creado, en su soledad, una pequeña porción de amor;/

habiedo creado, en su soledad, un corto

himno sagrado,/

reflexionó profundamente

sobre a quién hacer participe

del fundamento del lenguage humano;/

sobre a quién hacer partícipe del pequeño amor;/

sobre a quién hacer partícipe de las series de palabras que componían el himno sagrado.
Tendo aflorado, a sós, a fonte da futura fala,/ e desdobrado, a sós, um pouco de amor;/ tendo criado, a sós, um breve som sagrado,/ ele refletiu longamente sobre com quem compartilhar a fonte da fala;/ sobre com quem compartilhar o amor,/ com quem partilhar as fieiras de palavras do som sagrado./

Depois de muito meditar, com o saber contido em seu ser-de-céu/ e sob o sol de seu lume criador, desdobrou-se em quem refletiria seu ser-de-céu.

Vemos aí como o fundamento da fala, uma vez estabelecido, produz um estado de falta, e não de completude imperativa. Por isso, Ñamandu é levado a se desdobrar em seus outros. "Ñamandu", a rigor, não é nome de uma figura delimitada, não é um substantivo capaz de encerrar um sujeito ou essência individual, mas antes o indicativo de uma série de derivações. Não é por acaso que, na versão guarani apapocuva recolhida por Nimuendajú, encontramos Ñandevuruçu dialogando, já na cena inicial, com o seu par Ñanderú Mbaecuáa, "achado" (e não criado) por ele:

E Ñandevuruçu achou Ñanderú Mbaecuáa junto de si. E Ñandevuruçu disse a Mbaecuáa: “Áchemos uma mulher!" Então Ñanderú Mbaecuáa falou: "Como podemos achar uma mulher?" Disse Ñandevuruçu: "Nós a acharemos na panela de barro". 60

Vemos aí, mais uma vez, como a dualidade inicial esconde uma propensão para a multiplicidade, identificada através da proliferação de séries de nomes. Essas derivações em séries ${ }^{61}$ possuem um sentido muito similar ao de outras séries de nomes demiúrgicos tais como os "Maira" das narrativas tupinambá, os "Tokẽ" da narrativa marubo e os "Wanadi" do ciclo Watunna dos Yekuana - esses últimos, aliás, chamados de damodede uns dos outros, isto é, de “outras formas do espírito de Wanadi". ${ }^{62}$ Aí está uma das matrizes possíveis de sua equivocação enquanto divindade una (por Cadogan, por exemplo), reforçada ainda mais pela solidão de Ñamandu (mas já vimos que é toda outra esta espécie de solidão-mundo) ao longo de toda a parte inicial do Ayvu Rapyta. Eis o ponto central. ${ }^{63}$ Sua derivação nos demais Ñamandu - em Karai Ru Eté, Jakaíra Ru Eté, e Tupã Ru Eté, entre outros que se sucederão ao longo da narrativa - não é da ordem da relação entre criador e criatura, autor e obra, causa e efeito. A multiplicidade constitutiva dessa replicação nada tem a ver com a anterioridade, centralidade e coletividade do Pater. ${ }^{64} \mathrm{O}$ fundamento da palavra, sua realização enquanto voz capaz de "congregar" - o "Um que reúne" de Clastres, solução ao que ele via com excesso de cristianismo no "pequeño amor" de Cadogan, todas tentativas de tradução de mborayu, a ideia de socialidade, do que está destinado a reunir ${ }^{65}$-, é o fundamento de uma voz múltipla, recursiva, sem a qual o mundo não poderia existir. Reencontramos aqui o famoso argumento de Lévi-Strauss na Historie de lynx dedicado à ideologia bipartite dos ameríndios, que 
pressupõem dualidades em perpétuo desequilíbrio e não unidades estáveis ou pares simétricos. É nesse sentido que o antropólogo francês revisava os primeiros estudos dedicados ao mito de origem tupinambá recolhido e publicado por Thevet em 1575:

\begin{abstract}
Ehrenreich suivi par Métraux estime, probablement avec raison, que les divinités qui se succèdent et se remplacent au cours du récit n'ent forment qu'une seule; qu'elles sont, comme dit Métraux, des doublures les uns des autres; et qu'il faut aussi réduire à une seule les deux paires de jumeaux (issus respectivement de Sumé et de MaireAta). Peut-être; mais le fait de leur diffraction n'en est pas moins réel, car chacune de ces hypostases remplit une fonction spéciale. Les jumeaux de la première paire sont des antagonistes toujours en conflit; ceux de la deuxième paire sont des amis, associés dans toutes leurs entrerprises nonobstant des talents inégaux. Quant aux démiurges qui se sucèdent sur la scène du mythe, ils exercent tous une action séparatrice entre des termes dont l'extension et la compréhension vont diminuer ou bien changer la nature. ${ }^{66}$
\end{abstract}

\begin{abstract}
"Ehrenreich, seguido por Métraux, estima, provavelmente com razão, que as divindades que se sucedem e que se substituem ao longo da narrativa são apenas um uma; que elas são, como diz Métraux, desdobramentos umas das outras; e que devese reduzir também a apenas um os dois pares de gêmeos (derivados respectivamente de Sumé e de Maíra-Ata). Talvez, mas o fato de sua difração não é menos real, pois cada uma dessas hipóstases preenche uma função especial. Os gêmeos do primeiro par são antagonistas em conflito perpétuo; aquelas do segundo par são amigos, associados em todas as suas empreitadas e a despeito de seus talentos distintos. Quanto aos demiurgos que se sucedem na cena do mito, eles exercem todos uma ação separadora entre os termos cuja extensão e compreensão diminuem ou transformam a natureza." (trad. minha)
\end{abstract}

A virada da argumentação de Lévi-Strauss pode ser encontrada nesse seu "talvez", que desloca a ilusão monista de Ehrenreich e Métraux para uma compreensão mais acurada da instabilidade constitutiva da multiplicação por pares presente na narrativa tupinambá. Ora, a replicação dos nomes das divindades indica justamente isso: não sua repetição desnecessária ou inexata a escamotear a unidade que se confundiria no decorrer das narrativas (tupinambá e outras, como vimos), mas a replicação necessária (o seu "desdobramento", como queria Clastres) ou produção de multiplicidades intensivas ativadas pela voz. O problema da agência criadora, dessa forma, se dispersa na série, ao invés de se concentrar em um ponto focal primeiro. Ora, não é senão a partir do desdobramento em série que o mundo de fato vem a ser, e não antes ou a despeito de tal instabilidade. Daí, ao que tudo parece indicar, a limitação do modelo da dialogicidade: não tratamos aqui exatamente do reconhecimento e da emergência do Outro como matriz para a heteroglossia (Cf., De Man 1983). Não há ainda propriamente um Outro nessas cenas iniciais, assim como tampouco há outro Um. Nem a voz do Criador central, nem a dispersão polifônica entre um ou mais pessoas ou sujeitos, atuais ou potenciais (Bakhtin 2000, p. 354). É que os contornos do que seria um enunciador individual não se encontram ainda definidos; estamos, a rigor, em um horizonte pré-individual (cf., Viveiros de Castro 2002, p. 354), no qual as séries ordinais prevalecem sobre as unidades cardinais, as proliferações intensivas sobre as quantidades extensivas. Voz recursiva, capaz de produzir desdobramentos em série potencialmente infinitos: é isso que categorias duplicadoras tais como damodede ("duplo/alma", em yekuana), take ("irmão/duplo/derivação", em marubo) ou ñamandu (nome das séries demiúrgicas, em mbya-guarani) parecem pressupor: menos uma relação de alteridade radical (tal como a projetada pelo fantasma do solipsismo), mais uma duplicação-proliferação em cascata, capaz de projetar, na cena inicial, a voz intensiva das multiplicidades primeiras. ${ }^{67}$ 


\title{
V.
}

Como compreender a posição sempre instável dos atuais xamãs com relação às séries demiúrgicas primeiras? Incompatíveis com o Um, elas tampouco ocupam uma posição arquetípica, à qual os atuais viventes se reportariam como protótipo transcendental. Vimos acima como o xamanismo de cura dos povos do rio Negro replica as formas de nomeação realizadas pelos espíritos, na tentativa de garantir a eficácia de suas palavras ativadas pelo uso de substâncias psicoativas e de outros instrumentos. Vimos, também, como tal procedimento está constantemente sujeito às falhas, a despeito da infalibilidade do sistema cosmológico. Ainda que os xamãs contemporâneos repliquem os modos de ativação da palavra similares aos de outros tempos, eles não estão submetidos à palavra de uma autoridade única. Não são, por assim dizer, uma vox clamanti in deserto, indigna de desatar as sandálias de seu superior, que ora é concebido como libertador da interioridade individual (o Jesus do Evangelho de São João), ora como o Pai justiceiro coletivo da humanidade, para quem clamam as vozes e trombetas do Apocalipse (atribuído a outro João, o de Patmos) ${ }^{68}$

É outra a forma de mediação em questão. Os pajés Marubo, assim como os atuantes entre os Guarani e os Yanomami, reconhecem também um estado de indigência da humanidade, contraposto à magnificência dos espíritos. Esse reconhecimento, entretanto, produz um movimento de superação distinto da submissão ao deus sacrificado para expiar as máculas do mundo. O devir-espírito, incompatível com a separação entre humano e divino fundadora da metafísica cristã, se estabelece a partir de um plano de imanência. Yovea, a capacidade de se "espiritizar" (yove-a, espírito + verbalizador) arduamente perseguida pelo xamanismo marubo, não implica em uma imitação, em uma representação imaginária ou em uma identificação com o outro, mas sim na passagem para uma multiplicidade, que bem poderia ser pensada em conexão com as reflexões de Deleuze e Guattari em Mille plateaux: "uma multiplicidade não se define pelos elementos que a compõem em extensão, nem pelos caracteres que a compõem em compreensão, mas pelas linhas e dimensões que ela comporta em 'intensidade' [intension]". ${ }^{69} \mathrm{O}$ ponto é perceptível de maneira eloquente na seguinte passagem, em que o xamã yanomami Davi Kopenawa narra o seu processo de iniciação (diríamos, de devir-espírito) a partir do contato progressivo com os xapiri:

\begin{abstract}
Uma vez assim adornados, eles [os xapiri] nos levam para as costas do céu e nos deixam no centro de uma clareira, na qual farão sua dança de apresentação. $\mathrm{O}$ solo dessa clareira é um vasto espelho coberto por plumas brancas que cintilam em sua luminosidade ofuscante. Tudo isso é simultaneamente magnífico e assustador! É a nossa imagem que os espíritos acomodam em tal estado. De início, eles as extraem do interior de nossos corpos para colocá-las sobre os espelhos celestes. Durante esse tempo, nossa pele, muito enfraquecida, permanece deitada em casa, na floresta. Então, eles perturbam nosso pensamento e nossa língua, a fim de nos ensinar o deles. Em seguida, fazem-nos conhecer o desenho da floresta a fim de que possamos protegê-lo. Os xapiri são soberbos e resplandecem em sua luminosidade. Parecem frágeis, mas são muito poderosos. ${ }^{70}$
\end{abstract}

Os xapiri, assim como os yovevo dos Marubo, são por excelência uma multiplicidade. Não são, como dizíamos, uma quantidade, uma extensão, mas um fluxo de intensidade que permanece aí desde os tempos primeiros (os mesmos referentes aos episódios acima comentados) e que se torna parcialmente acessível às pessoas viventes através da ativação de 
estados de devir. ${ }^{71}$ Tais estados são alcançados por uma série de procedimentos rituais, mais uma vez, ameaçados pela falha. Note a importância da perturbação do pensamento e da língua comuns, fundamental para que se conquiste o acesso aos outros modos de linguagem, tornado possível a partir da dissolução do que conceberíamos como um sujeito, da destruição de seus contornos individuais e de sua recomposição no fluxo intensivo.

Os erros realizados pelos humanos ao longo de determinados eventos que poderiam ter sido bem sucedidos costumam, não por acaso, servir de mote para depoimentos que replicam, através de uma estrutura narrativa similar, os deslizes também cometidos pelos agentes dos tempos primeiros (por nós chamados de "míticos"). Em um estudo recente dedicado ao xamanismo guarani mbyá, Daniel Pierri trata do caso de um xamã que fracassa em sua tentativa de atingir o estado de aguyje (traduzido pelo antropólogo como "maturação corporal"72), pelo qual se tornaria uma divindade Nhanderu Mirim (também concebível, aliás, como uma multiplicidade similar às dos xapiri e yovevo ${ }^{73}$ ). No relato abaixo, o xamã se lamenta por não ter conseguido pegar o fogo que, sabia ele, havia sido deixado por Tupã em uma montanha. Em vez de ir buscar logo a dádiva de Tupã, o xamã priorizou outros compromissos que tinha na cidade e, só no dia seguinte, foi ao lugar escolhido. Ao chegar ali, encontra apenas uma árvore seca, sem as chamas enviadas pelo demiurgo:

\begin{abstract}
Era uma árvore grande que tinha caído. Já estava queimada até o fim. Mas nós procuramos por tudo e percebi que tinha acabado de apagar. Tava quente ainda, mas não tinha mais brasa, só estava quente. Já tinha apagado tudo. Puxa vida, tive pena, e dali em diante eu comecei a errar, aos poucos, sem perceber. Nhanderu Tupã trouxe o fogo para nós. Para que não usássemos o fogo rekoaxy. Para a gente saber usar, para que tivéssemos o fogo bom. Não o fogo do jurua. Nisso nós erramos. E por isso fiquei aqui mesmo. Eu não tô falando isso só por mim, me mostraram a morada do Nhanderu e da Nhandexy que tem pra lá. Então, eu comecei a adoecer de novo [...]. ${ }^{74}$
\end{abstract}

Se tivesse sido mais cuidadoso, o xamã teria conseguido pegar o fogo deixado por Tupã, ao invés de usar o fogo ordinário de nosso mundo. Assim, poderia alterar o seu padrão alimentar e atingir a maturação corporal, pela qual poderia, ainda em vida, passar à Terra Sem Mal. O depoimento se vale de um processo similar ao de outras narrativas referentes aos tempos primeiros, tais como a história de Roka contada pelos Marubo. ${ }^{75}$ Cansado de viver em um mundo outrora assolado pelas doenças, o antepassado Roka decide subir para a morada celeste acompanhado de sua mulher. Antes de partir, convida os seus parentes e oferece-lhes, entre outras coisas melhores, o seu fogo-descamar (shoko txi) que rejuvenesce por propiciar a troca de pele. Antepassado Jacaré, no entanto, entende que Roka havia pedido para ele cortar a própria língua e deixa de buscar o fogo. É por isso que os jacarés possuem, nos dias de hoje, a língua curta. Além da analogia pelo fogo, ambas as narrativas colocam em jogo a falha de uma figura ao tentar conquistar o estado melhor que lhe havia sido oferecido por outra figura marcada, não por uma posição hierárquica inatingível, mas por uma assimetria potencialmente reversível através do esforço ritual. Depreende-se da narrativa marubo que o jacaré (exhumano) passa a ocupar uma posição análoga à dos atuais humanos, cuja troca de pele só pode ser conquistada após a morte. Roka, na narrativa, conclama seus parentes a adotar um estado melhor através de uma espécie de aconselhamento (e não de uma ordem), que termina por ser mal absorvido e por gerar determinadas consequências etiológicas. Nos tempos presentes, a obtenção de uma condição melhor em vida é um alvo constante das alterações xamanísticas, que buscam contornar a morte através da progressiva familiarização da pessoa com seus 
parentes-espírito. Assim, ela se tornaria capaz de abandonar sua carcaça e antecipar a passagem para outras posições. São poucos, contudo, aqueles que conseguem atingir tal estado: suas histórias e feitos dão margem a conversas constantes, nas quais os mais comuns lamentam os seus fracassos. ${ }^{76}$

Tais convergências mostram que a possibilidade do devir não poderia jamais ser falsa, mesmo que nem todos consigam atingi-lo: "o que é real é o próprio devir, o bloco de devir, e não os termos supostamente fixos pelos quais passaria aquele que devém" $77 \mathrm{O}$ devirmultiplicidade, reativado pela voz nos xamanismos contemporâneos e envolvido na definição dos xamãs de outrora (correspondentes a estes que costumam ser traduzidos por deuses ou espíritos), se refere a um modo de existência ou uma "ontologia", algo que não pode ser testável ou explicável em sua totalidade, mas que se manifesta em determinados ajustes ou desajustes pragmáticos. ${ }^{78} \mathrm{O}$ trabalho de tradução é uma dessas manifestações pontuais de divergência entre modos de existência, notável, como vimos, na pressuposição de um agente divino uno por Cadogan.

Algo, entretanto, ainda parece estar fora do lugar. As cenas primeiras, assim como os procedimentos rituais contemporâneos, são constituídos pela falibilidade de seus agentes, sejam eles humanos ou "hiper" (divindades, espíritos). Ora, mas os xapiri, diz Davi Kopenawa, não mentem jamais, ao contrário dos humanos. O mesmo diriam outros tais como os xamãs Marubo, para os quais o conhecimento dos espíritos é também infalível, muito além do alcance de nossa compreensão comum. Entretanto, as falhas ocupam um lugar estrutural evidente nas narrativas que, além do mais, estendem tal motivo para os procedimentos rituais contemporâneos. Como lidar com esse suposto descompasso? Talvez ele esconda uma lição, além daquela já conhecida, de que o pensamento narrativo constrói suas complexidades através de aparentes incoerências. A falha não é necessariamente um sinal de fraqueza, o pesadelo do comando imperativo que encontra no fracasso uma ameaça ao seu poder. Ao contrário, ela é uma estratégia de abertura, de distribuição da agência em uma série, que tem com forma expressiva a voz múltipla.

\section{Referências bibliográficas}

Bakhtin, Mikhail. [1979]. Estética da criação verbal. São Paulo: Martins Fontes, 2000.

Clastres, Pierre. La société contre l'État. Paris, Les Éditions de Minuit. 1974.

Danowski, Déborah \& Viveiros de Castro, Eduardo. Há mundo por vir? Ensaio sobre os medos e os fins. São Paulo/ Florianópolis: Instituto Socioambiental/ Editora Cultura e Barbárie, 2014.

DeLanda, Manuel. Intensive science and virtual philosophy. Nova York/ Londres: Bloomsbury, 2002.

De Man, Paul. "Dialogue and dialogism". In: Poetics today Vol. 4, No 1, 1983, pp. 99-107.

Frye, Northrop. [1982]. Código dos códigos - a Bíblia e a literatura. São Paulo: Boitempo Editorial, 2004.

Jullien, François. Procès ou création. Paris: Seuil, 1989.

Zumthor, Paul. A letra e a voz. São Paulo: Companhia das Letras, 2001.

\section{Notas de fim}

\footnotetext{
${ }^{1}$ Agradeço a Roberto Zular pela leitura e comentários à primeira versão deste artigo.

${ }^{2}$ Bíblia de Jerusalém, São Paulo, Paulus Editora, 2002.
} 
3 Relato aikewara (povo falante de Tupi-Guarani) recolhido por Orlando Calheiros e citado por Danowski \& Viveiros de Castro (2014, p. 87).

${ }^{4}$ A discussão pode ser encontrada nos recentes debates sobre o conceito de "antropoceno", tais como os que têm sido reunidos no ambicioso Anthropocene Project, curado por Anselm Franke desde 2013. Viveiros de Castro também tem se dedicado a refletir sobre o assunto em suas últimas conferências ("Notícias sobre o fim do mundo", Universidade de São Paulo, 2013) e publicações (ver Danowski \& Viveiros de Castro, 2014)

${ }^{5}$ Elohim (Gênesis I.1 a II.3), a primeira divindade descrita pelo seu caráter transcendente e monológico, é a que nos traz a imagem de partida fundamental para este artigo. A segunda (o demiurgo do Gênesis II,4 em diante, que corresponde ao nome inefável YHVH e à outra tradição narrativa, mais antiga do que aquela que deu origem ao primeiro extrato narrativo da Bíblia) se aproxima por sua vez da esfera humana e introduz não apenas a possibilidade do diálogo como, também, da própria falha de que decorre o pecado original (Cf. Campos, 2000, p. 32; Frye, 2004, p. 135; Bíblia de Jerusalém, p.33). As duas aberturas (a falha e o diálogo de Javé-Deus), contudo, de forma alguma deixariam de tornar significativas as diferenças entre os regimes ontológicos ameríndios e cristãos, profundamente assentadas que estão em distintas concepções cosmopolíticas de autoridade (ver para tanto os conhecidos argumentos de Clastres, 1974, e de Viveiros de Castro, 2002, pp. 181-265). Para um contraste similar ao aqui proposto, vale remeter ao trabalho de Francois Jullien sobre o pensamento clássico chinês (em especial sobre pensador confucionista Wang Fuzhi, séc. XVIII), para o qual não faz sentido a fixação no logos e em seu poder de autoridade criadora, mas sim uma ausência de ação (em especial da ação vertical sobẹrana) em favor da influência (taixu) como forma de mediação de um Céu que "não tem necessidade de falar", pois "tudo é receptível ao seu influxo, de adesão imediatạ" (Jullien 1989: 37). Tal disposição do Sábio com relação ao Processo $(D a o)$, alheia à acão criadora originária do comando verbal, contrasta de maneira muito evidente com o legado deixado pelo demiurgo autoritário do Gênesis, por exemplo, na Idade Média cristã. E o que encontramos na seguinte passagem de Zumthor: "A idéia do poder real da palavra, idéia profundamente ancorada nas mentalidades de então, gera um quadro moral do universo. Todo discurso e ação, física e psiquicamente efetiva. Donde a riqueza das trađicões orais, contrárias ao que quebra o ritmo da voz viva. O Verbo se expande no mundo, que por seu meio foi criado e ao qual dá vida. Na palavra se origina o poder do chefe e da política, do camponês e da semente. $\mathrm{O}$ artesão que modela um objeto pronuncia as palavras que fecundam seu ato. Verticalidade luminosa que jorra das trevas interiores, fundadas sobre os paganismos arcaicos, ainda marcados por esses traços profundos, a palavra proferida pela Voz cria o que ela diz." (1993, p. 75). Na sequência, veremos como os regimes amerindios de pensamento projetam dilemạs próprios, tão incompatíveis com a Voz hierárquica cristã quanto aqueles referentes às matrizes taoístas-confucionistas.

${ }^{6}$ Gordon Brotherston e Sérgio Medeiros (org.), Popol Vuh, São Paulo, Iluminuras, 2007, p. 12.

7 Jack Himelblau, "The Popol Vuh of the Quiche Maya of Guatemala: Text, Copyist and Time Frame of Transcription", Hispania, vol. 72, no. 1, 1989, pp. 97-122; Brotherston e Medeiros, Popol Vuh, op. cit., p. 14.

${ }^{8}$ Idem, p. 43

${ }^{9}$ Dennis Tedlock, Popol Vuh, Nova York, Touchstone, 1985, p. 71.

10 Tedlock sinaliza seu desconforto com a noção, de criação na seguinte passagem: "The generation: isso quer dizer uinakiric. Outros traduziram por 'criação', mas isso tambem tem a ver com processos tais como o surgimento sazonal de fontes em lugares que costumam ser secos, bem como com o crescimento e formação de algas ou de larvas na água parada. A palavra 'çriação' é carregada demais pelo pressuposto de uma prioridade ontológica do espiritual com relação ao material para ser importada ao presente relato das origens, que não contém nenhuma palavra similar". (Tedlock, Popol Vuh, op. cit., p. 249, n. 73 - tradução minha.) Voltaremos a isso adiante.

11 Idem, pp. 264-265.

12 Brotherston e Medeiros, Popol Vuh, op. cit., p. 51.

${ }^{13}$ Idem, p. 265 - tradução minha.

14 Tedlock, Popol Vuh, op. cit., p. 73.

15 Idem, p. 253.

16 Idem, ibidem.

${ }^{17}$ A diferença poderia ser compreendida através de um caso distinto, mas referente à impregnação da noção de sacrifício indo-europeia em outras ontologias, tal como propõe Luc de Heusch (Le Sacrifice dạns les religions africaines, Paris, Gallimard, 1986, p. 17) em seu trabalho sobre o sacrifício nas religiões tradicionais africanas. Para o papel do sacrifício expiador da humanidade e sua relacão com a voz de autoridade paterna, veja Mladen Dolar, A Voice and Nothing More, Cambridge, The MIT Press, 2006, p. 53 e ss.

18 Dennis Tedlock, The Spoken Word and the Work of Interpretation, Filadélfia, The University of Pennsylvania Press, p. 269.

${ }^{19}$ Muito embora não seja anotada por Tedlock, a diferença entre o deus dos extratos javista e eloísta do Gênesis mereceria aqui ser observada (ver nota 2 supra.).

${ }^{20}$ Idem, p. 270.

${ }^{21}$ Brotherston e Medeiros, Popol Vuh, op. cit., pp. 64-65.

${ }^{22}$ Para uma reflexão sobre o contexto de produção da coleção e das elaborações do livro no Alto Rio Negro, consulte Geraldo Andrello "Falas, objetos e corpos - Autores indígenas no Alto Rio Negro", Revista Brasileira de Ciências Sociais, vol. 73, no. 25, 2010, pp. 5-26; e Stephen Hugh-Jones, "Entre l'image et l'écrit. La politique tukano de patrimonialisation en Amazonie", Cahiers des Amériques Latines 63-64, 2010, pp. 195-227.

${ }^{23}$ Américo Castro Fernandes e Durvalino Moura Fernandes, Bueri Kãdiri Maririye - Os ensinamentos que não se esquecem, São Gabriel da Cachoeira, FOIRN, União das Nações Indígenas do Rio Tiquié, 2006, p. 19.

${ }^{24}$ Idem, p. 24. 
${ }^{25}$ Miguel Azevedo e Antenor Nascimento Azevedo, Mitologia sagrada dos Tukano Hausirõ Porã, São Gabriel da Cachoeira, FOIRN/ União das Nações Indígenas do Rio Tiquié, 2003, p. 21.

${ }^{26}$ Idem, p. 29.

${ }^{27}$ Wenceslau Sampaio Torãmu Bayaru Galvão e Raimundo Castro Guahari Ye Ni Galvão, Livro dos antigos Desana - Guahari Diputiro Porã, São Gabriel da Cachoeira, FOIRN/ONIMRP, 2004, p. 27.

${ }^{28}$ Umúsin Panlõn Kumu e Tolamãn Kenhíri, Antes o mundo não existia - A mitologia heróica dos índios desâna, São Paulo, Livraria Cultura Editora, 1980.

${ }^{29}$ Galvão e Galvão, Livro dos antigos Desana, op. cit., p. 51.

${ }^{30}$ Idem, p. 53.

31 Dominique Buchillet, "Personne n'est là pour écouter: les conditions de mise en forme des incantations therapeutiques chez les Desana du Uaupés brésilien", Amerindia 12, 1987, pp. 7-32.

32 Idem, p. 7.

${ }^{33}$ Pedro de Niemeyer Cesarino, Oniska - Poética do xamanismo na Amazônia, São Paulo, Perspectiva, 2011.

${ }^{34}$ Veja Cesarino (Oniska, op. cit.) para um estudo e traduções mais detalhadas de tais cantos.

${ }^{35}$ Pierre Clastres, La société contre l'État, Paris, Les Éditions de Minuit, 1974.

36 Pedro de Niemeyer Cesarino (org.), Quando a Terra deixou de falar-Cantos da mitologia marubo, São Paulo, Editora 34, 2013, pp. 46-49.

37 Veja Cesarino (Oniska, op. cit., p. 194) para mais detalhes sobre os classificadores empregados pelo pensamento marubo. Não se trata de adjetivos, mas de marcadores sociocosmológicos capazes de indicar a classe ou o segmento a que pertencem pessoas, elementos, entidades extra-humanas e demais formas de existencia do cosmos.

${ }^{38}$ Cesarino, Oniska, op. cit., p. 49.

39 Curt Unkel Nimuendajú, As lendas da criação e destruição do mundo como fundamentos da religião dos Apapocúva-Guarani, São Paulo, Hucitec/Edusp, 1987, p. 143.

${ }^{40}$ León Cadogan, Ayvu Rapyta - Textos míticos de los Mbyá-Guaraní del Guairá, Asunción, Ceaduc-Cepag, 1997, p. 29.

41 Tal é o caso das antigas cosmogonias gregas (cf. G.S. Kirk, J. E. Raven e M. Schofield, Os filósofos présocráticos, trad. Carlos Alberto Louro Fonseca, Lisboa, Calouste Gulbenkian, 1994, p. 17; F.M. Cornford, Principium sapientiae - As origens do pensamento filosófico grego, trad. Maria Manuela Rocheta dos Santos, Lisboa, Calouste Gulbenkian, 1989, p. 305). A originalidade ontologịca das matrizes narrativas ameríndias parece também se contrapor à seguinte base derivada do monoteísmo hebraico-cristão, tal como explicada por Cornford: "A diferenca mais notável em relacão às cosmogonias gregas está em que o monoteísmo hebraico reteve o Criador divino como causa primeira. Fora disso, nâo há personificações míticas como Eros ou Fanes. E a ação de Elohim é limitada ao ato de proferir a palavra criadora. Tornou-se uma figura extremanente abstrata e remota." (op. cit., p. 326). A despeito do tratamento de Cornford do extrato eloísta do Gênesis (ver também Haroldo de Campos, Bere'shith - A cena da origem, São Paulo, Perspectiva, 2000, p. 32) como uma "evolução quase científica do cosmos", cujos pressupostos não nos interessam aqui, é interessante ressaltar, em primeiro lugar, a retenção da identificação do Criador como causa primeira e, em segundo lugar, a ideia, também partilhada com as antigas cosmogonias gregas, da "separação ou diferenciação a partị de uma confusão prịmitiva" (idem ibidem). $\mathrm{O}$ trecho de Cornford em questão também remete às antigas personificações míticas associadas ao Ovo cósmico e suas formas de proliferação genética, que parecem distintas dos casos em pauta.

${ }^{42}$ Pierre Clastres, A fala sagrada - Mitos e cantos dos índios guarani, trad. Nícia Adan Bonatti, Campinas, Papirus, 1990, p. 20.

${ }^{43}$ Cf. Jadran Mimica, Intimations of Infinity - The Cultural Meanings of the Iqwaye Counting and Number

Systems, Oxford, Berg, 1988, p. 74.

44 Idem, p. 22.

${ }^{45}$ Idem, p. 77.

${ }^{46}$ Cf. Roy Wagner, "The Fractal Person" in Marilyn Strathern e Maurice Godelier (org.), Big Men and Great Men: Personifications of Power in Melanesia, Cambridge, Cambridge University Press, 1991.

${ }^{47}$ Clastres, A fala sagrada, op. cit., p. 22.

48 Idem, p. 26.

${ }^{49}$ Cadogan, Ayvu Rapyta, op. cit., p. 33.

50 Josely Vianna Baptista, Roça barroca, São Paulo, Cosac Naify, 2011, p. 31.

51 Essas considerações se inspiram naquelas elaboradas por Marilyn Strathern para as noções de pessoa e de agência na Melanésia, que não se compreendem através da associação do agente à posição do indivíduo, como no caso ocidental (The Gender of the Gift, Berkeley, The University of California Press, 1988, p. 268), mas devidamente transformadas para a presente situação etnográfica.

52 Veja por exemplo Cadogan, Ayvu Rapyta, op. cit., p. 41.

${ }^{53}$ Cf. Dolar, A Voice and Nothing More, op. cit., p. 40.

${ }^{54}$ Para uma problematização da noção de mito, ver Marcel Detienne, L'Invention de la mythologie, Paris, Gallimard, 1981.

55 Vale a pena reproduzir a passagem de Lévi-Strauss: "O mito poderia ser definido como modo do discurso em 
que o valor da fórmula traduttore traditore tende praticamente a zero. Quanto a isso, seu lugar, na escala dos modos de expressão linguística, é oposto ao da poesia, por mais que se tenha procurado aproximá-los. A poesia é uma forma de linguagem extremamente difícil de traduzir em outra língua, e toda tradução acarreta deformações múltiplas. O valor do mito, ao contrário, permanece, por pior que seja a traducão." (Claude Lévi-Strauss, Antropologia estrutural, trad. Beatriz Perrone-Moisés, Săo Paulo, Cosac Naify, 2008, p. 225). A noção de mito em Lévi-Strauss, é importante recordar, envolve a totalidade de suas variantes, de modo que, por exemplo, o Edipo de Freud e o de Sófocles devem ser considerados como o mesmo mito. Ainda assim, as torçôes ontologicas derivadas do trabalho de tradução não deixam de fazer com que o mito se transforme em outra coisa para quem o recebe com outros pressupostos ontológicos, diretamente relacionados às qualidades ou opcoes poéticas selecionadas no texto traduzido. A discussão, que mereceria ser desenvolvida com mais detalhes em outra oportunidade, terminaria por desembocar no problema da equivocidade tradutória recentemente tratado por Viveiros de Castro ("Perspectival Anthropology and the Method of Controlled Equivocation", Tipití, vol. 2, no. 1, 2004, pp. 3-20).

${ }^{56}$ Não se trata aqui, evidentemente, de fidelidade no nível das relações éticas e pessoais, com as quais Cadogan era certamente comprometido, tanto ou mais ainda do que os outros tradutores do Ayvu Rapyta. Refiro-me à fidelidade tradutória (conceitual, estética e ontológica).

${ }^{57}$ Clastres, A fala sagrada, op. cit., p. 30.

${ }^{58}$ Cadogan, Ayvu Rapyta, op. cit., p. 35.

${ }^{59}$ Vianna Baptista, Roça barroca, op. cit., p. 35.

${ }^{60}$ Nimuendajú, As lendas da criação e destruição do mundo..., op. cit., p. 143.

${ }^{61}$ Cf. Gilles Deleuze, Logique du sens, Paris, Les Éditions de Minuit, 1969, p. 42.

${ }^{62}$ Marc de Civrieux, Watunna - An Orinoco Creation Cycle, trad. David Guss, San Francisco, North Point Press, 1980 p. 21. Em sua monografia sobre os Yekuana, David Guss explica que "as Primeiras Pessoas não tinham 'duplos' chamados de akato, mas sim damodede. Por contraste ao akato dos humanos ordinários, passivo e incontrolável, o damodede é uma alma independente que pode ser direcionada. [...] Para aqueles que possuem damodede, a forma tomada pelo corpo é irrelevante, assim como as barreiras entre realidades se tornam apenas transparências a serem facilmente transcendidas. As Primeiras Pessoas viviam tal como os atuais xamãs, em um estado polimorfo carente de fronteiras". (To Weave and Sing - Art, Symbol and Narrative in the South American Rain Forest, Berkeley, The University of California Press, 1989, p. 52 - tradução minha.) Isso permitia a Guss interpretar as diversas aparições de Wanadi na Terra da seguinte forma: "Wanadi apareceu na terra três vezes, cada uma como uma encarnação separada do damodede do outro Wanadi invisível que vive no Kahuña [LugarCéu]." (idem, p. 53). Ainda que não tenha elementos para discutir a etnografia yekuana, talvez não seja impertinente observar que Guș parece contaminado por certa visão isolacionista dos "seres" divinos, como se cada um, justamente por sua unicidade, fosse um ser separado dos outros, capaz de encarná-los alternadamente.

${ }^{63}$ Parece acontecer aí uma clivagem interessante com relação às séries regressivas indefinidas, disparadas pela proliferação de alternâncias entre nomes reais e nomes que designam sua realidade (isto é, o seu sentido) de que trata Deleuze em Logique du sens a partir dos textos de Lewis Carroll. No caso guarani, os nomes sucessivos, de uma maneira intrigante, também designam o sentido de seus anteriores, na medida em que o Demiurgo-Nome inicial se desdobra em outros Demiurgos-Nome seguintes que exprimem e ativam aspectos apenas potencialmente presentes no primeiro ponto da serie. E o que vemos em um trecho traduzido por Clastres ( $A$ fala sagrada op. cit., p. 32), no qual Namandu (n1) dá surgimento a Namandu de Grande Coração (n2), Karai (n3), Jakaira (n4) e Tupã (n5), designados como "Pais verdadeiros das numerosas crianças que estão por vir": um atributo latente, mas não evidente em n1. A série de Namandus n2-n5, şe completa, portanto, com o nome-epíteto (ne1) "Pais verdadeiros de seus numerosos filhos que estão por vir" que, por sua vez, é sucedido por oụtro epiteto (ne2), "Verdadeiros pais da palavra que habitará os numerosos fillhos que estão por vir", que designa o sentido do anterior ao explicitar que eles não são exatamente pais dos filhos que estão por vir, mas sim os verdadeiros pais da Palavra, que habitará os fillhos que estão por vir e assim por diante. Isso atesta também, como o problema da agência nã̃o poderia estar concentrado em uma figura centrạl individualizada (o Pai da metafísica cristã): a proliferação de nomes, que corresponde à sucessăo de designações de sentido, revela a lógica da agência partilhada ao longo da série. Daí, também, a provável inadequação do termo "deus", excessivamente marcado pela metafísica monista cristã, para a tradução dos processos em questão.

64 Veja, a respeito disso, a seguinte passagem de Benveniste sobre o termo indo-europeu *pater: "Ora, nessa figuracão original, está excluída a relação de paternidade física. Estamos fora do parentesco estrito, e * pater não pode designar o 'pai' no sentido pessoal. Não se passa de uma acepção à outra com tanta facilidade. São duas representações distintas, e, conforme as línguas, elas podem se mostrảr irredutíveis entre si. Para evidenciar essa diferença, voltaremos às observações de um missionário, W. G. Ivens, que relatou sua experiência no Pacífico ocidental. Ao tentar traduzir os Evangelhos para o melanésio, o mais difícil, disse ele, foi verter o Pater noster, pois nenhum termo melanésio corresponde à conotação coletiva de Pai.; 'A, paternidade nessas línguas é somente uma relação pessoal e individual'; um 'pai' universal é inconcebível". (Émile Benveniste, $O$ vocabulário das instituicôes indo-europeias, trad. Denise e Eleonora Bottmann, Campinas, Editora da Unicamp, vol. I, 1995, pp 208-209.) O problema remete à nota precedente acerca do problema da traducão de mitos em Lévi-Strauss: até que ponto o processo de tradução não envolve também um deslocamento ontológico das matrizes narrativas?

${ }^{65}$ Clastres, A fala sagrada, op. cit., pp. 29-32.

${ }^{66}$ Claude Lévi-Strauss, Histoire de lynx, Paris, Plon, 1991, pp. 75-77.

${ }^{67}$ Para o contraste entre intensivo e extensivo e seus desdobramentos, ver DeLanda, Manuel (2002).

${ }^{68}$ Cf. Gilles Deleuze, Critique et clinique, Paris, Les Éditions de Minuit, 1993.

${ }^{69}$ Gilles Deleuze e Félix Guattari, Mille plateaux, Paris, Les Éditions de Minuit, 1980, p. 299.

${ }^{70}$ Bruce Abert e Davi Kopenawa, La Chute du ciel - Paroles d'un chaman yanomami, Paris, Plon, 2010, p. 129 tradução minha.

${ }^{71}$ Cf. Eduardo Viveiros de Castro, A inconstância da alma selvagem, São Paulo, Cosac Naify, 2002, p. 354; e “A floresta de cristal: notas sobre a ontologia dos espíritos amazônicos", Cadernos de campo, no. 14/15, 2006, pp. 321-322. 
72 Essa maturação corporal, atingida através de rituais e de condutas alimentares específicas (entre as quais privilegiar o consumo do porco queixada ao invés de alimentos e carnes derivados da dieta dos brancos), será responsável por conduzir a pessoa a uma das moradas celestes, assim escapando do apodrecimento na terra. Vale se reportar à explicação de Pierri: “Cadogan (1997 [1959]) traduz aguyje por 'plenitude' ou 'perfeição', tradução que considero excessivamente cristã. Prefiro a traducão maturacão corporal, proposta por Viveiros de Castro (1986, p. 597) porque em outros contextos, aguyje é utilizado na língua mbya para indicar o estado de maturação de frutas. Diz-se, por exemplo, yvapurü'a ma ijaguyje ('A jabuticaba está madura')." (Daniel Calazans Pierri, $O$ perecivel e o imperecível - Logica do sensivel e corporalidade no pensamento guarani-mbya, dissertação de mestrado, Faculdade de Filosofia, Letras e Ciências Humanas, Universidade de São Paulo, 2013, p. 41)

${ }^{73}$ Idem, p. 165.

${ }^{74}$ Idem, p. 226.

75 Cesarino, Quando a Terra deixou de falar, op. cit., p. 207.

${ }^{76}$ Cf. Cesarino, Oniska, op. cit., p. 55.

${ }^{77}$ Deleuze e Guattari, Mille plateaux, op. cit., p. 291.

78 Cf. Mauro William Barbosa Almeida, "Caipora e outros conflitos ontológicos”, $R @ u$, vol. 5, no. 1, 2013, pp. 7$28,13$. 